\title{
Risk-oriented approach to problem of centrifugal pumps reliabilization during operation
}

\author{
Bikmukhametova Marina Aleksandrovna \\ Department of technological machines and equipment \\ Ufa state petroleum technological university, USPTU \\ Ufa, Russia \\ maribik@mail.ru
}

\author{
Tukaeva Rimma Borisovna \\ Department of technological machines and equipment \\ Ufa state petroleum technological university, USPTU \\ Ufa, Russia \\ tukaeva_rb@mail.ru
}

\author{
Bikmukhametov Anton Timurovich \\ Department of technological machines and equipment \\ Ufa state petroleum technological university, USPTU \\ Ufa, Russia \\ Antonbik@mail.ru
}

\begin{abstract}
The article shows that more progressive strategies are those of the fourth generation maintenance and repair based on reliability and repair management (RCM/RBI analysis, riskoriented technologies) of technological equipment maintenance and repair (M\&R) which have not found wide application in Russia. There are no guidelines on risk assessment during operation of production facilities and, particularly, of centrifugal pumps (CP). For developing risk assessment methodology for centrifugal pumps during operation, a new approach is suggested. It is based on application of the expert method for determining criticality and failure probability.
\end{abstract}

Forms of expert poll for various level specialists from oil refinery and petrochemical enterprises are developed and approved. Their analyses indicate that there is discordance of opinions of experts from oil refinery plants and of experts from petrochemical enterprises on significance level of $\mathrm{CP}$ failure causes.

Failure causes have been ranked in order of criticality and occurrence probability so as the result can be used in definition of optimal strategy and failure-response tactics applied to pump units and to increasing their reliability.

Key words-reliability, risk, centrifugal pump, operation stage, failure criticality, failure ranking.

\section{INTRODUCTION}

In accordance with the Project of branch development, strategy refining slowdown up to $8 \%$ is allowed in Russia till 2020 [1]. From this perspective, large oil companies channel their core capital not to the construction of new units or oil refinery plants (ORP) but prefer to invest in modernization of their operational capacities.

Nowadays the concept 'digital plant', which involves online condition monitoring of every unit, every equipment element in combination with each production stage, is becoming a tool for solving modernization problems.
Accordingly, solutions for monitoring and analysis of industrial processes on a real time basis, managing maintenance and repair (M\&R), on-line processing, etc. will have high demand among ORPs.

Thereupon, implementation of progressive systems, including $M \& R$ capable to reduce the risk of emergency initiation, to increase the operation reliability of processing equipment (PE) and to decrease the $M \& R$ costs per unit significantly, assumes prominence at enterprise modernization. This is particularly true for solution of the problem for pump units (PU) as more than $60-70 \%$ of all PE failure falls to PU. M\&R strategies being used nowadays can be roughly divided into 4 generations [2]. The most innovative strategies, which find wider application abroad, are strategies of the fourth generation based on controlling reliability and risks ( $\mathrm{RCM} / \mathrm{RBI}$ analysis, risk-oriented technologies)

The technologies of repair control based on reliability as well as condition monitoring for equipment and production processes allow decreasing technological risk factors.

The mixed method of centrifugal unit M\&R combining planned preventive maintenance (PPM) and conditionmonitored (CM) repair with the application of the vibrationbased diagnostics mainly dominates in domestic enterprises. It is known that in Russia this strategy (technology) has been implemented in a few companies only such as Gazprom Neft PJSC, in 8 plants of Lukoil PJSC, in Omsk ORPs and others. Implementation of the complex system of risk analysis and reliabilization, which allows getting significant positive results, is a strategic objective for all the Gazprom Neft companies [3]. However, these technologies in other Russian enterprises are being implemented very slowly.

In order to implement any new M\&R strategy into refinery enterprises, the regulatory technical documents (RTD) standardizing its application and being consistent with ROSTECHNADZOR must be worked out. One of the major tasks assigned in the present work was to work out effective 
RTD recommended for centrifugal pumps $M \& R$, while the other one is to consider the possibility of developing and implementing a new strategy into oil refinery and petrochemical (PCh) enterprises of the Republic of Bashkortostan.

Analysis of the main regulatory technical documents recommended for centrifugal pump M\&R in ORP [4. 5. 6. 7. 8. 9] has shown the lack of any guidelines on risk assessment on the stage of processing equipment operation and, particularly, of centrifugal pumps. There are several documents providing the definition of 'risk assessment' [10. 11] and giving recommendations on assessing a risk of processing equipment but at the stage of its designing and repair only [12. 13]. In general, there is a lack of system work with collecting, processing and analysis of equipment state data that is one of the main shortcomings in M\&R control.

Therefore, it is recommended to carry out implementation of a modern and high performance risk-oriented strategy of pump unit maintenance and repair as soon as possible in order to increase equipment reliability by means of providing acceptable level of failure risks, optimizing $M \& R$ costs, increasing time between overhauls, reducing the repair term, etc.

One of the key aspects in the risk-oriented approach is identification and risk assessment of processing equipment (PE) failure. The peculiarity of maintenance strategy based on the risk assessment is taking one more measuring into consideration - probability of equipment failure [11]. Combined study of criticality of the equipment and probability (frequency) of its shut down which can be determined on the basis of the available failure statistics or by the expert method allows to find the risk level (criticality) going along with the equipment operation.

Accordingly, for implementing this strategy in every enterprise there must be a database on the breakdown and failure statistics, their causes with due consideration of specific operation conditions, failure ranking in order of criticality, etc. Additionally, in our opinion, the statistics data published in science and research literature can be used for risk identification.

\section{RESULTS AND DISCUSSIONS}

The literature analysis has shown that data on determination of centrifugal pump risks is not fully available. There are only some anecdotal reports. For instance, in the work [14] a risk assessment of centrifugal pumps at the design stage is given.

Within the framework of the risk analysis the authors have taken into consideration the factors and hazard types in accordance with the technical regulation of the Customs Union TR CU 010/2011 'On the safety of machinery and equipment', as well as hazard types not given in the framework of the technical regulation but common for the pump design [13].
Failure criticality has been determined in accordance with GOST 27.310-95 'Analysis of types, consequences and criticality of failures. The main provisions ' [14].

In the present work, the methodology developed by the authors and dedicated to $\mathrm{CP}$ risk assessment during operation is described. It is based on the expert approach. The task was solved with the participation of a group of experts that filled in the developed forms of the expert poll and interrogatory test making it possible to identify probable hazard types connected with PE operation, to identify failure criticality (FC) and to rank the failures in order of criticality.

In accordance with [14] FC was estimated as a product of

$$
\mathrm{KO}=\mathrm{B}_{1} \mathrm{~B}_{2} \mathrm{~B}_{3}
$$

where $\mathrm{B}_{1}$ is the characteristic of failure frequency; $\mathrm{B}_{2}$ is the failure effect evaluation; $\mathrm{B}_{3-}$ is the probability evaluation of failure detection.

In the present work multipliers $\mathrm{B}_{1}, \mathrm{~B}_{2}$ and $\mathrm{B}_{3}$ included into equation 1 were evaluated by the expert way applying our recommendations in grades (from 1 to 10).

For identification of pump failure criticality, the following classification of pump elements risk level was taken in the paper:

1. $0-100$ - low risk level;

2. 101-200 - intermediate risk level;

201 and more - high risk level.

As preliminary analysis of the polling forms, filled by the experts from different plants, showed the data for oil refinery plants differs from those for petrochemical (PCh) enterprises. Therefore, all the assessments were systemized into two groups. One group is with answers of the experts from ORP and the other one is with answers of the experts from petrochemical enterprises.

In calculations, maximum departure from the factor mean value did not exceed 20\%. In Figure 1 results of the first stage of risk assessment and criticality level identification are represented in grades depending on the parameter in question. In the present paper, the assessment was carried out using 20 parameters. Figures $1 \mathrm{a}$ and $1 \mathrm{~b}$ represent results of risk assessment provided by the experts of OPR and of PCh respectively. Figure 2 shows generalized estimations of all the experts wherein the failure causes ranked in order of criticality decrease are located along $\mathrm{x}$-axis. The data analysis given in the figure shows that according to the expert assessments of both OPR and petrochemical enterprises the following parameters have high criticality:

- failure of a face seal (parameter 20);

- failure of control devices, control instrumentation and protection devices (parameter 19);

- depressurization of flange couplings (parameter 17);

- overload capacity excess of basic operating conditions (temperature, pressure and flowrate), uneven warming of pump components (parameter 14). 
Analysis of the obtained data reveals discordance of expert opinions on significance level of other $\mathrm{CP}$ failure causes. According to the first expert group, they are given in order of significance: structural integrity damage in auxiliary, supply and export pipelines, breach of maintenance and repair regulations and of safe pump operation rules, torque retention loss in thread joints, disconnection of anchor and couplings in pipelines, valves as a result of vibration.

According to the second expert group, most $\mathrm{CP}$ failures happen because of the failure of thrust and radial bearings, structural integrity damage and failure of seals and gaskets, failure of electric equipment elements, wiring insulation fault, appearing of cracks and fractures in bearing and supporting pump structures, components and pipelines as a result of dynamic load effects, fatigue effects and corrosion.

In order to explain this discordance, it is necessary to conduct further analysis with participation of additional number of experts.

Tables 1 and 2 show failure ranking in order of criticality and probability of its occurrence for OPR and petrochemical enterprises respectively. Herewith the following levels were used for classification of failure probability:

1. from 1 to 3 - low level of failure probability;

2. from 4 to 6 - intermediate level of level of failure probability;

3. from 7 to 10 - high level of failure probability.

Therefore, components whose failures contain high-risk parameters are determined for centrifugal pumps during operation.

Within the framework of staff training on pump application we can recommend to carry out procedures of familiarization and knowledge test with the risk assessment results including the most common pump failures and personnel error which can lead to critical effects and to work out a strategy and failure-response tactics applied to pump units either.

Analysis and extermination of the reasons causing these failures are one of the major tasks, which we are planning to solve for quick implementation of risk-oriented $\mathrm{M} \& \mathrm{R}$ strategy.

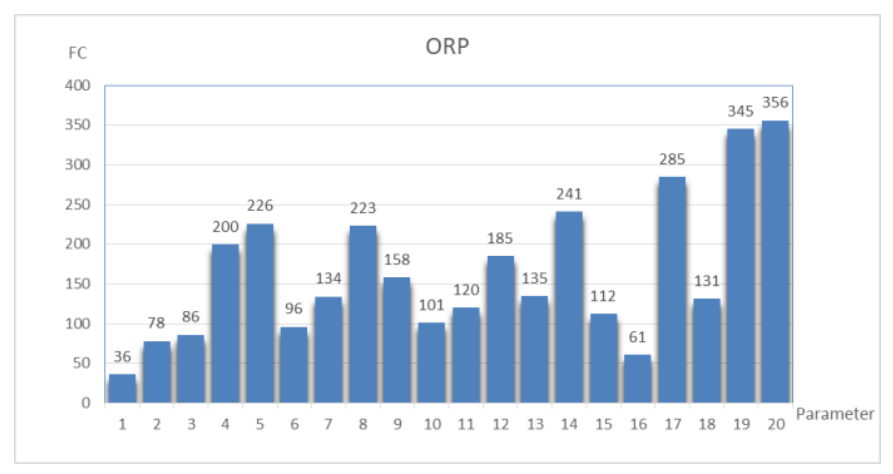

a)

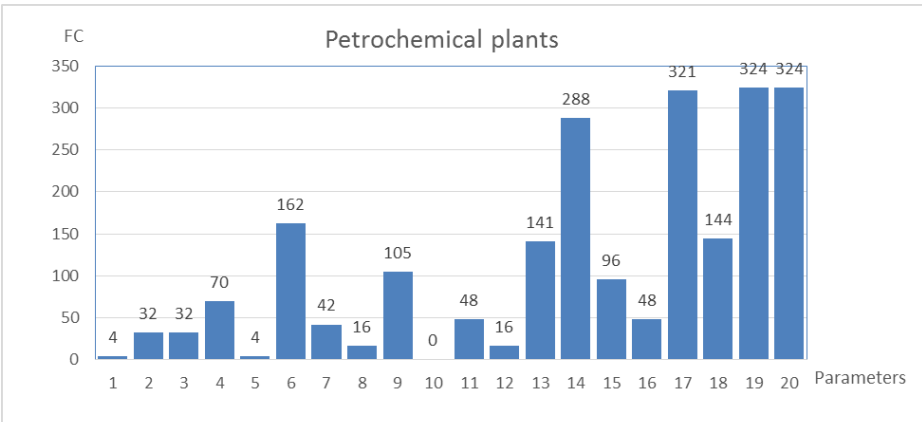

b)

1. Foundation damage and unfastening of pump unit frame 2. Cracks in a case, unfastening of mounting face for bearings 3. Damage (runout) of a shaft, rotor, blades 4. Damage of bearings (thrust and radial) 5. Structural integrity damage and failure of seals and gaskets 6. Structural integrity damage in auxiliary, supply and export pipelines 7. Failure of a drive motor 8 . Failure of electric equipment elements, wiring insulation fault 9 . Failure of a lubrication system (including deficit of lubrication in bearing cases) 10. Failure of a water-cooling system (including deficit of water in the system) 11. Presence of mechanical impurities in pumped medium 12. Occurrence of cracks, fractures in bearing and supporting pump constructions, components and pipelines as a result of dynamic load effects, fatigue effects and corrosion 13 . Torque retention loss in thread joints, disconnection of anchor and couplings in pipelines, valves as a result of vibration 14 . Overload capacity excess of basic operating conditions (temperature, pressure and flowrate). Uneven warming of pump components 15. Depreciation of rotor elements (shaft, impeller and its blades) 16. Hydraulic shock in pipelines and pump wet end 17. Depressurization of flange couplings 18. Breach of maintenance and repair regulations and of safe pump operation rules 19. Failure of control devices, control instrumentation and protection devices (shut-off and control valves, relief valves, etc.) including pump operation with the defective devices mentioned above 20. Failure of a face seal unrecorded in the poll

Fig.1. Identification of failure criticality (FC) in grades depending on the parameter in question

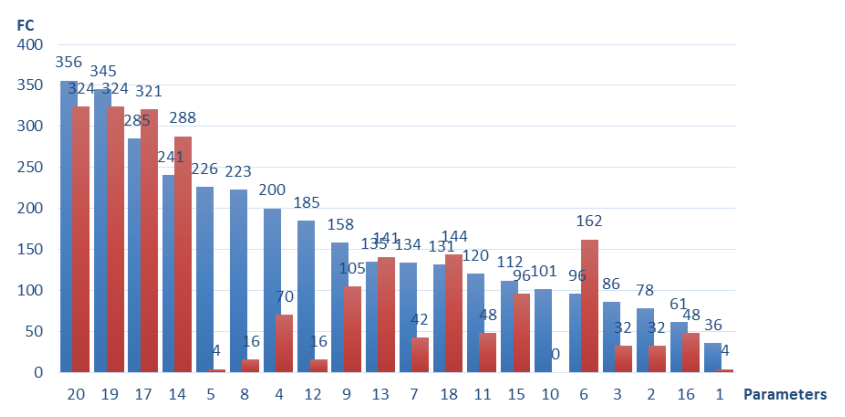

Fig.2. Results of the expert assessment of centrifugal pump failure criticality (FC) during operation 
TABLE I.

FAILURE RANKING IN ORDER OF CRITICALITY AND FAILURE PROBABILITY (PETROCHEMICAL ENTERPRISES)

\begin{tabular}{|c|c|c|c|c|c|c|c|}
\hline \multirow{2}{*}{$\begin{array}{l}\text { Para } \\
\text { mete } \\
\text { r No }\end{array}$} & \multirow[t]{2}{*}{ Parameter name } & \multicolumn{3}{|c|}{$\begin{array}{l}\text { Failure criticality } \\
\text { (FC) }\end{array}$} & \multicolumn{3}{|c|}{ Failure probability } \\
\hline & & $\begin{array}{l}\mathrm{Hi} \\
\mathrm{gh}\end{array}$ & $\begin{array}{c}\text { Interme } \\
\text { diate }\end{array}$ & $\begin{array}{c}\text { Lo } \\
\mathrm{w}\end{array}$ & $\begin{array}{l}\mathrm{Hi} \\
\mathrm{gh}\end{array}$ & $\begin{array}{c}\text { Interme } \\
\text { diate }\end{array}$ & $\begin{array}{c}\text { Lo } \\
\mathrm{w}\end{array}$ \\
\hline 19 & $\begin{array}{l}\text { Failure of control } \\
\text { instrumentation and } \\
\text { protection devices } \\
\text { (shut-off and control } \\
\text { valves, relief valves, } \\
\text { etc.) }\end{array}$ & & & & & & \\
\hline 20 & $\begin{array}{l}\text { Failure of a face seal } \\
\text { unrecorded in the } \\
\text { poll }\end{array}$ & & & & & & \\
\hline 17 & $\begin{array}{l}\text { Depressurization of } \\
\text { flange couplings }\end{array}$ & & & & & & \\
\hline 14 & $\begin{array}{lr}\text { Overload } & \text { capacity } \\
\text { excess of basic } \\
\text { operating conditions } \\
\text { (temperature, } \\
\text { pressure rand } \\
\text { flowrate). Uneven } \\
\begin{array}{l}\text { warming of pump } \\
\text { components }\end{array}\end{array}$ & & & & & & \\
\hline 6 & $\begin{array}{l}\text { Structural integrity } \\
\text { damage in pipelines }\end{array}$ & & & & & & \\
\hline 18 & $\begin{array}{l}\text { Breach } r \text { of } \\
\text { maintenance and } \\
\text { repair regulations } \\
\text { and of safe pump } \\
\text { operation rules }\end{array}$ & & & & & & \\
\hline 13 & $\begin{array}{l}\text { Torque retention loss } \\
\text { in thread joints as a } \\
\text { result of vibration }\end{array}$ & & & & & & \\
\hline 9 & $\begin{array}{l}\text { Failure of } \quad \text { a } \\
\text { lubrication system }\end{array}$ & & & & & & \\
\hline 15 & $\begin{array}{l}\text { Depreciation of rotor } \\
\text { elements (shaft, } \\
\text { impeller and its } \\
\text { blades) }\end{array}$ & & & & & & \\
\hline 4 & $\begin{array}{l}\text { Damage of bearings } \\
\text { (thrust and radial) }\end{array}$ & & & & & & \\
\hline 7 & $\begin{array}{l}\text { Failure of a drive } \\
\text { motor }\end{array}$ & & & & & & \\
\hline 11 & $\begin{array}{l}\text { Presence of } \\
\text { mechanical } \\
\text { impurities in pumped } \\
\text { medium }\end{array}$ & & & & & & \\
\hline 16 & $\begin{array}{l}\text { Hydraulic shock in } \\
\text { pipelines and pump } \\
\text { wet end }\end{array}$ & & & & & & \\
\hline 2 & $\begin{array}{l}\text { Cracks in a case, } \\
\text { unfastening } \\
\text { mounting face for } \\
\text { bearings }\end{array}$ & & & & & & \\
\hline 3 & $\begin{array}{l}\text { Damage (runout) of a } \\
\text { shaft, rotor, blades }\end{array}$ & & & & & & \\
\hline 12 & $\begin{array}{lr}\text { Occurrence } & \text { of } \\
\text { cracks, fractures in } \\
\text { bearing } & \text { and } \\
\text { supporting } & \text { pump } \\
\text { constructions } & \end{array}$ & & & & & & \\
\hline 8 & $\begin{array}{l}\text { Failure of electric } \\
\text { equipment elements, } \\
\text { wiring insulation } \\
\text { fault }\end{array}$ & & & & & & \\
\hline
\end{tabular}

TABLE I. CONT.

\begin{tabular}{|l|l|l|l|l|l|l|l|}
\hline 5 & $\begin{array}{l}\text { Structural integrity } \\
\text { damage and failure } \\
\text { of seals and gaskets }\end{array}$ & & & & & & \\
\hline 1 & $\begin{array}{c}\text { Foundation damage } \\
\text { and unfastening of } \\
\text { pump unit frame }\end{array}$ & & & & & & \\
\hline 10 & $\begin{array}{c}\text { Failure of a water- } \\
\text { cooling system }\end{array}$ & & & & & & \\
\hline
\end{tabular}

TABLE II. FAILURE RANKING IN ORDER OF CRITICALITY AND FAILURE PROBABILITY (ORP)

\begin{tabular}{|c|c|c|c|c|c|c|c|}
\hline \multirow{2}{*}{$\begin{array}{l}\text { Paramete } \\
\text { r No }\end{array}$} & \multirow[t]{2}{*}{ Parameter name } & \multicolumn{3}{|c|}{ Failure criticality (FC) } & \multicolumn{3}{|c|}{ Failure probability } \\
\hline & & High & \begin{tabular}{|c|} 
Interme \\
diate
\end{tabular} & Low & High & $\begin{array}{c}\text { Interme } \\
\text { diate }\end{array}$ & Low \\
\hline 19 & $\begin{array}{lr}\text { Failure of control } \\
\text { instrumentation } \\
\text { protection and } \\
\text { (shut-off and } \\
\text { valves, relief } \\
\text { etc.) }\end{array}$ & & & & & & \\
\hline 20 & $\begin{array}{l}\text { Failure of a face seal } \\
\text { unrecorded in the poll }\end{array}$ & & & & & & \\
\hline 17 & $\begin{array}{l}\text { Depressurization } \\
\text { flange couplings }\end{array}$ & & & & & & \\
\hline 14 & $\begin{array}{lrr}\text { Overload } & \text { capacity } \\
\text { excess of } & \text { basic } \\
\text { operating conditions } \\
\text { (temperature, pressure } \\
\text { and flowrate). } \\
\text { warming of } \\
\text { componen } \\
\text { comprents }\end{array}$ & & & & & & \\
\hline 5 & $\begin{array}{l}\text { Structural integrity } \\
\text { damage and failure of } \\
\text { seals and gaskets }\end{array}$ & & & & & & \\
\hline 8 & $\begin{array}{l}\begin{array}{l}\text { Failure of electric } \\
\text { equipment } \\
\text { elements, } \\
\text { wiring insulation fault }\end{array} \\
\end{array}$ & & & & & & \\
\hline 4 & $\begin{array}{l}\text { Damage of bearings } \\
\text { (thrust and radial) }\end{array}$ & & & & & & \\
\hline 12 & $\begin{array}{lr}\text { Occurrence of } & \text { cracks, } \\
\text { fractures in bearing and } \\
\text { supporting } \\
\text { constructions }\end{array}$ & & & & & & \\
\hline 9 & $\begin{array}{l}\text { Failure of a lubrication } \\
\text { system }\end{array}$ & & & & & & \\
\hline 13 & $\begin{array}{l}\text { Torque retention loss in } \\
\text { thread joints as a result } \\
\text { of vibration }\end{array}$ & & & & & & \\
\hline 7 & Failure of a drive motor & & & & & & \\
\hline 18 & $\begin{array}{l}\text { Breach of maintenance } \\
\text { and repair regulations } \\
\text { and of safe pump } \\
\text { operation rules }\end{array}$ & & & & & & \\
\hline 11 & $\begin{array}{l}\text { Presence of mechanical } \\
\text { impurities in pumped } \\
\text { medium }\end{array}$ & & & & & & \\
\hline 15 & $\begin{array}{l}\begin{array}{l}\text { Depreciation of rotor } \\
\text { elements } \\
\text { (shaft, } \\
\text { impeller and its blades) }\end{array} \\
\end{array}$ & & & & & & \\
\hline 10 & $\begin{array}{c}\text { Failure of a water- } \\
\text { cooling system }\end{array}$ & & & & & & \\
\hline 6 & $\begin{array}{l}\text { Structural integrity } \\
\text { damage in pipelines }\end{array}$ & & & & & & \\
\hline
\end{tabular}


Table II. Cont.

\begin{tabular}{|c|c|c|}
\hline 3 & $\begin{array}{l}\text { Damage (runout) of a } \\
\text { shaft, rotor, blades }\end{array}$ & \\
\hline 2 & $\begin{array}{llr}\text { Cracks in a } & \text { case, } \\
\text { unfastening } & & \text { of } \\
\text { mounting } & \text { face } & \text { for } \\
\text { bearings } & & \\
\end{array}$ & \\
\hline 16 & $\begin{array}{l}\text { Hydraulic shock in } \\
\text { pipelines and pump wet } \\
\text { end }\end{array}$ & \\
\hline 1 & $\begin{array}{c}\text { Foundation damage and } \\
\text { unfastening of pump } \\
\text { unit frame }\end{array}$ & \\
\hline
\end{tabular}

\section{CONCLUSION}

Thus, consideration of the risk level will allow one to balance terms and scopes of equipment M\&R laying down the order of their execution priority which will generally lead to increase of time between overhauls, decrease of M\&R costs, improvement of reliability and operation safety both of the pump equipment and of overall production operations.

In the present paper, initial steps on development of the risk-oriented approach applied to centrifugal pumps during operation are represented.

\section{REFERENCES}

[1] M.A. Meizler, M.A. Bikmukhametova, R.B. Tukaeva, "New approach to development of risk assesment tools of centrifugal pumps", Materials of the 45th International Scientific and Technical Conference of Young Scientists, Postgraduates and Students, pp. 139-141, April 2018 [45th International Scientific and Technical Conference of Young Scientists, Postgraduates and Students, Ufa, USPTU, p. 270, 2018].

[2] V.I. Bobrovitskii, A.V.Sidorov, "Development of equipment M\&R system under the conditions of centralization of enterprise maintenance service", Machinery vibration: measurement, decrease, protection, Donetsk: DonNTU, vol.1 (24), pp. 23-28, 2011.

[3] E.I. Kopalidi, S.A. Lapkin, V.R. Rzhevkin, A.B. Samokhvalov, "Experience in implementation of risk management system and equipment reliability based on PCMS software", Strategy of operation, maintenance, carrying out of residual and capital repairs of objects at oil refining and petrochemical enterprises: proceedings of the meeting, pp. 118-129, April 2016 [Strategy of operation, maintenance, carrying out of residual and capital repairs of objects at oil refining and petrochemical enterprises, M: LLC NTC at the council of main mechanichs, p. 448, 2016].

[4] Regulation for the system of equipment maintenance and repair in petrochemical productions, enterprises of chemical and oil refinery industry, MPCP USSR. Ufa, 1981, p. 179.

[5] Regulation for scheduled preventive maintenance of process equipment at oil refinery and petrochemical industry, MPCP, Volgograd, 1977, p.187;

[6] General technical specifications for centrifugal pump repair. UO 38.12.018-94, MTE RF, Volgograd, 1995, p. 291.

[7] Manual on conducting diagnostic measurements of enterprise centrifugal compressors and centrifugal pump units, MPCP USSR, Moscow, 1991 (appr. 12.04.91), p. 53.

[8] GOST ISO 7919-1-99. Evaluation of machine vibration by measurements on rotating shafts. M.: PPC Standard Publishing, 2000, p. 40 .

[9] FNiP General rules on explosion safety for explosive- and firehazardous chemical/petrochemical plants and oil refineries, Moscow: STC Industrial safety CJSC, 2013, p. 126.

[10] GOST R ISO 31000-2010 «Risk management. Principles and guidelines», M.: Standartinform, 2012, p. 21.

[11] GOST R 51901.11 - 2005 (IEC 61882:2001) «Risk management. Hazard and operability studies», M.: Standartinform, 2006, p. 42.

[12] GOST ISO 13372-2013. Mechanical vibration, shock and condition monitoring. Terms and definitions, M.: Standartinform, 2014, p. 19.

[13] TR CU 010/2011 "On the safety of machinery and equipment.", Approved by the commission of the CU, 2011, p. 66;

[14] GOST 27.310-95 "Analysis of species, consequences and criticality of failures. Basic regulations».- M.: PPC Standard Publishing, 1996, p. 20. 